\title{
Creative Scenario Options For Regional Economy Development
}

\author{
Abdulxakimov Zuhrali Tursunalievich \\ Senior Lecturer, Namangan Institute of Engineering and Technology, Republic of \\ Uzbekistan, EconomicsDoctor of Philosophy \\ abdulxakimov@gmail.com \\ Abdul Rahmat \\ Gorontalo State University, Indonesia \\ abdulrahmat@ung.ac.id
}

Received: 12 Januari 2021; Revised: 26 Februari 2021; Accepted: 28 April 2021

DOI: http://dx.doi.org/10.37905/aksara.7.239-246.2021

\begin{abstract}
This article explores ways to develop small areas within the regions of the Republic of Uzbekistan and develops scenario options for small areas.

Keywords: World economy, innovation, technology, science-intensive industries, modernization, conservative, scientific integration.

\section{INTRODUCTION}

Under the influence of profound structural changes in the world economy, significant changes have taken place in the world agricultural sector. For this reason, any changes in the agricultural system must be accompanied by innovative approaches. The process, which has a special place in the economic development of the world economy, is formed by the introduction of new economic concepts, the production of new high-tech computer-information products in the economy, the mass production of science-intensive products. Under the influence of changes in the investment climate, the development of competition, changes in attitudes to human capital, support for innovative development of the economy, a system of agro-industrial clusters is formed in the agricultural system of high-tech industries. The organization and acceleration of the development of agro-industrial clusters as effective mechanisms of economic development under the influence of innovative innovations in agriculture of the country. The first scientific developments on innovation were made by J. Schumpeter in the twenties of the twentieth century. It is also called "news diffusion".
\end{abstract}

\section{MAIN PART}

In the development of the country's economy, first of all, it is necessary to determine the level of development of the regions, as well as the gradual development of the regions within the regions. One of such areas is Yangikurgan district of Namangan region of the Republic of Uzbekistan. Several development strategies have been developed and put into practice in the development of the district. The conservative scenario scenario is based on the intensive development of Yangikurgan district of Namangan region. Significant development of the 
district's economy will be achieved as a result of the development and implementation of socio-economic development programs until 2030 "Yangikurgan city" and "Nanay tourist cluster". Yangikurgan district is a district with high economic potential, but the district has not developed ways to effectively use this potential, one of the main reasons for which is the lack of integration with research organizations and direct integration with the regional scientific potential. It is a mistake to think that this is the mistake of the heads of provinces or districts, and today a new system is being created in this area. As a result of the implementation of "Scientific integration" of scientific developments in cooperation with the districts, additional opportunities will be created, additional jobs will be created. The scientific developments developed by the research organizations for the development of the economy will be put directly into practice in the district economy, and a new technological structure and high results will be achieved as a result of providing investments in the well-targeted developments.Modernization scenario - It is planned to gradually increase the average level of socio-economic development of Yangikurgan district. Modernization begins the stages of renewal in the district networks, initially developing new scientific proposals for production and services, which are fastacting and based on the specific characteristics of the district.

\section{RESULTS AND DISCUSSION}

Innovative scenario - involves the achievement of high rates of economic growth and social development through the involvement of innovations (innovations) in the economy of the district. It is expedient to direct the investments of the district mainly in the field of modernization and innovation. It is necessary to introduce the results of the fifth and sixth industrial sectors in the production and service sectors of the district.Results and discussion. . Based on the above results, it will be necessary to prepare targeted projects. Innovative development and creation of attractive living conditions as a result of innovative renewal of the district's economy In Yangikurgan district it will be possible to implement the concept "Innovation and modernization covers all areas, a convenient option for living, studying, working and leisure in Yangikurgan district." As a result of the above growth, Yangikurgan district will be in the process of integration with the CIS and Central Asian countries, and Yangikurgan region will become one of the leading innovative regions in the country, in particular. 


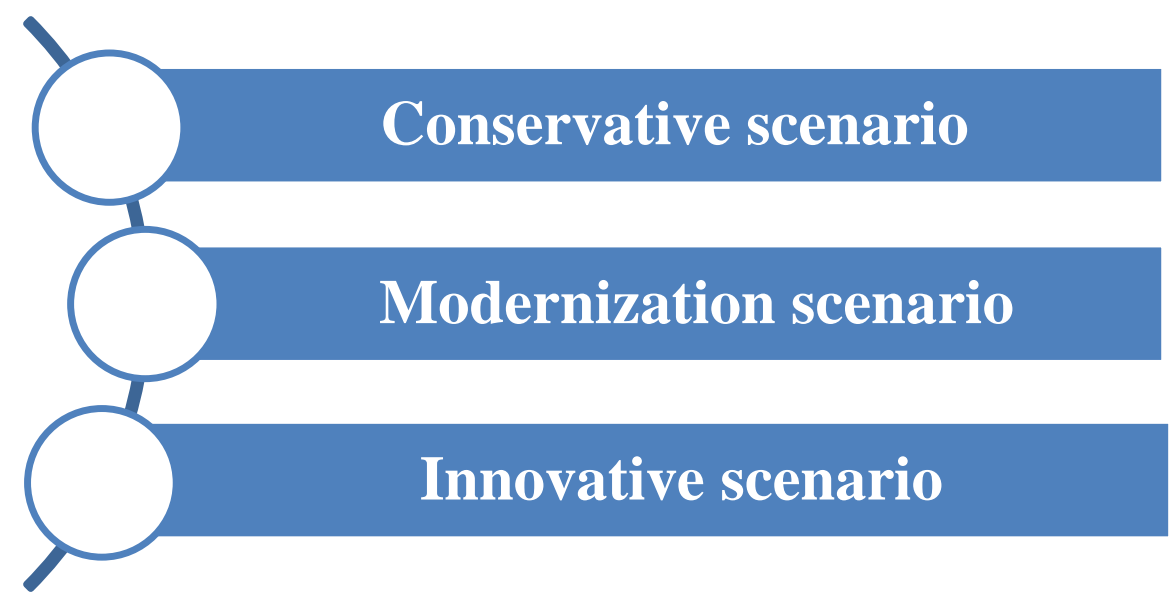

Figure 1. Scenario of economic and social development of Yangikurgan district In our opinion, the above scenario options will provide Yangikurgan district with a new pace of development, turn the district into an "Innovation Zone". To do this, these innovative changes will need to be prepared based on the characteristics and capabilities of the district.

"Today, the situation with the modernization, technical and technological re-equipment of production in the leading sectors of the economy requires serious attention." This is because the conditions of a market economy require industrial enterprises to adapt to market requirements, and the main condition for their operation is the level of their technical and technological equipment, the latest achievements in science and technology. This ensures that they produce a competitive product.

Table 1. The main features of the long-term development scenario of Yangikurgan district

\begin{tabular}{|c|c|c|c|c|}
\hline № & $\begin{array}{l}\text { A characteristic } \\
\text { feature of } \\
\text { scenarios }\end{array}$ & $\begin{array}{l}\text { Conservative } \\
\text { scenario }\end{array}$ & $\begin{array}{l}\text { Modernization } \\
\text { scenario }\end{array}$ & $\begin{array}{l}\text { Innovative } \\
\text { scenario }\end{array}$ \\
\hline 1. & $\begin{array}{c}\text { Characteristic } \\
\text { feature of scenarios }\end{array}$ & $\begin{array}{c}\text { Significant structural } \\
\text { changes in the socio- } \\
\text { economic } \\
\text { development of } \\
\text { Yangikurgan and } \\
\text { Nanay tourist } \\
\text { clusters until 2030 }\end{array}$ & $\begin{array}{c}\text { Existing problems of } \\
\text { socio-economic } \\
\text { development of } \\
\text { Yangikurgan town } \\
\text { and Nanay tourist } \\
\text { clusters until } 2030 \\
\text { and ways to solve } \\
\text { them }\end{array}$ & $\begin{array}{l}\text { Wide introduction } \\
\text { of large-scale } \\
\text { innovations in all } \\
\text { spheres of socio- } \\
\text { economic } \\
\text { development of } \\
\text { Yangikurgan town } \\
\text { and Nanay tourist } \\
\text { clusters until } 2030\end{array}$ \\
\hline 2. & $\begin{array}{l}\text { Demographic } \\
\text { development }\end{array}$ & $\begin{array}{l}\text { Regulation of the } \\
\text { high level of } \\
\text { demographic } \\
\text { situation of the } \\
\text { population of the } \\
\text { district; Regulation } \\
\text { of internal and } \\
\text { external migration; } \\
\text { Increasing life } \\
\text { expectancy to } 72 \\
\text { years }\end{array}$ & $\begin{array}{l}\text { Achieving intensive } \\
\text { population growth; } \\
\text { Organization of } \\
\text { targeted migration } \\
\text { routes through } \\
\text { vocational training } \\
\text { and retraining; } \\
\text { Increasing life } \\
\text { expectancy to } 78 \\
\text { years; }\end{array}$ & $\begin{array}{l}\text { Ensuring natural } \\
\text { population growth; } \\
\text { Focus on skilled } \\
\text { labor in migration; } \\
\text { Increasing life } \\
\text { expectancy to } 80 \\
\text { years }\end{array}$ \\
\hline
\end{tabular}




\begin{tabular}{|c|c|c|c|c|}
\hline 3. & Social development & $\begin{array}{l}\text { Modernization of } \\
\text { the social shell; } \\
\text { Development of } \\
\text { norms of per capita } \\
\text { income of the } \\
\text { population; } \\
\text { Develop } \\
\text { mechanisms to } \\
\text { support the lower- } \\
\text { than-average strata } \\
\text { of district incomes }\end{array}$ & $\begin{array}{c}\text { Radical } \\
\text { modernization of the } \\
\text { social shell; } \\
\text { Reducing the gap } \\
\text { between incomes; }\end{array}$ & $\begin{array}{l}\text { Implementation of } \\
\text { innovative changes } \\
\text { through new } \\
\text { approaches to } \\
\text { solving social } \\
\text { problems; } \\
\text { Ensuring } \\
\text { sustainable } \\
\text { development of the } \\
\text { middle class; } \\
\text { Increase the } \\
\text { average income of } \\
\text { the population of } \\
\text { the district and } \\
\text { develop } \\
\text { mechanisms of } \\
\text { social support }\end{array}$ \\
\hline
\end{tabular}

\section{CONCLUSION}

New innovative changes in the agricultural system, which plays an important role in the country's economy, and the organization of forms of ownership are among the pressing issues. At the same time, rather than exporting raw materials to the world market, the export of agricultural products as a finished product is a comprehensively effective direction. As one of such practical works, the accelerated development of the economy of the regions is one of the most effective directions in all respects. Today, concepts such as "cluster", "clusterization", "cluster policy" are entering through the organization due to the changes of the period. The organization of clusters in the economy consists of the creation of new types of directions based on the organization of innovative activities, as well as the interaction of closely related industries and the harmonization of services in the district and region.

In the development of regions, digital technologies evolve in interdependence and interdependence over time.

\section{REFERENCES}

Islyaev R.A. Strategy of social and economic development of the Republic of Crimea until 2030.

Action Strategy on the five priority areas of development of the country for 20172021, provided by the Decree of the President of the Republic of Uzbekistan dated February 7, 2017 "On the Action Strategy for further development of the Republic of Uzbekistan".-T .: Uzbekistan, 2017

Тухтасинова, Д. Р. (2019). Теоритические Основы Совершенствования Технологии Антикризисного Управления На Предприятиях. Апробация, (4), 77-79.

.Тухтасинова, Д. Р. (2018). Инновация и модернизация экономики. In роль человеческого капитала в социально-экономическом развитии (pp. 124127). 
.Муминова, Э. А., \& Тухтасинова, Д. Р. (2016). The problems of financingenterprises in the condition of innovative activity. Символ науки, (12-1).

Muminova, Elnorakhon and Tukhtasinova, Dildora (2019) "THE ISSUES OF DEVELOPMENT OF FINANCING OF INVESTMENT PROJECTS BY COMMERCIAL BANKS," Scientific Bulletin of Namangan State University: Vol. 1 : Iss. 8 , Article 23. Available at: https://uzjournals.edu.uz/namdu/vol1/iss8/2

Dodxomirzaevich, S. S., Mamadjanovich, Y. K., \& Axrorbek, M. (2020). A Review On Fusion Of Different Defogging Techniques To Clear Im Improving Private Education Service In Public-Private Partnership. International Engineering Journal For Research \& Development, 5(Special Issue), 6-6.

Юлдашев, К. М., \& Холмирзаев, А. Х. (2019). Осуществление реализации механизма частного партнерства в Узбекистане. Молодой ученый, (51), 435-437.

Tursunalievich, A. Z. (2020). Establishment And Use Of Small Eco-Zones In The Development Of Recreational Activities. InternationalEngineeringJournalForResearch\&Development, 5( Speciallssue), 7-7.

Ikromjonovna, I. N., Abdulaxad, S., \&Tursunalievich, A. Z. (2020). Establishment Of Agricultural Clusters In Agriculture. International Engineering Journal For Research \& Development, 5(Special Issue), 8-8.

Abduganievich, A. U., Bakhriddinovich, I. R., \&Tursunalievich, A. Z. (2020). Development Of Physical Training And Sports In The Republic Of Uzbekistan. InternationalEngineeringJournalForResearch\&Development, 5 (SpecialIssue), 8-8.

Abduganievich, A. U., Bakhriddinovich, I. R., \&Tursunalievich, A. Z. (2020). Development Of Physical Training And Sports In The Republic Of Uzbekistan. InternationalEngineeringJournalForResearch\&Development, 5 (SpecialIssue), 8-8.

Tursunalievich, A. Z., \&Bakturdievich, I. E. (2020). Treatment And Rehabilitation Of Tourism And Recreation. InternationalEngineeringJournalForResearch\&Development, 5 (Speciallssue), 8-8.

Abdurashidovich, B. D., Bakhriddinovich, I. R., Tursunalievich, A. Z., \&Zokirjonovich, K. Q. (2020). Issues Of Small Business And Private Entrepreneurship Development. International Engineering Journal For Research \& Development, 5(Special Issue), 7-7.

Ismoilov, R. B., Mullabayev, B. B., \&Abdulxakimov, Z. T. (2020). Prospects For The Development Of A Tourist Route" Safed Broth Or Horn Jarir". TheAmericanJournalofInterdisciplinaryInnovationsandResearch, $2(0$ 8), 38-44.

Ismoilov, R. B., Mullabayev, B. B., Abdulxakimov, Z. T., \&Bakhriddino, J. R. O. (2020). The Essence Of Small Business And Private Entrepreneurship And The Theoretical Basis Of Its Development. TheAmericanJournalofAppliedsciences, 2(08), 45-50. 
Aliyev, Y. (2020). Минтақавий Туристик-Рекреацион Мажмуаларни Ташкил Этишда Давлат-Хусусий Шерикчилик Тизимини Ривожлантириш. Архив научных исследований, (19).

Tursunalievich, A. Z. (2019). Senior Teacher of the Namangan Engineering and Technology Institute. Scientific and analytical journal «Science and Practice» of Plekhanov University, 11(1), 33.

Abdulxakimov, Z. T., \&Raxmonjonov, R. S. (2019). Attracting Investments To The Economy. Prioritiesforensuringtheeconomicsecurityofthecountry, 1(4), 3.

Abdulhakimov, Z. T. (2018). Establishment of tourism and recreational facilities and recreational facilities in Namangan region. EconomicsandInnovativeTechnologies, 2018(4), 15.

Bakhriddinovich, I. R., Bulturbayevich, M. B., Gulomjanovna, M. N., \&Karimjanovich, U. R. (2020). Use Of Modern Marketing Research In The Context Of Market Development. InternationalEngineeringJournalForResearch\&Development , 5(SpecialIssue), 8-8.

Abdurashidovich, B. D., Bakhriddinovich, I. R., \&Bulturbayevich, M. B. (2020). The State Of Development Of Small Business And Private Entrepreneurship During The Coronavirus Pandemic. InternationalEngineeringJournalForResearch\&Development, 5( Speciallssue), 8-8.

Abduganievich, A. U., Bakhriddinovich, I. R., \&Bulturbayevich, M. B. (2020). Current Situation Of Investment In The National Economy. International Engineering Journal For Research \& Development, 5(Special Issue), 7-7.

Bulturbayevich, M. B., Saodat, S., \&Shakhnoza, N. (2020). Innovative Activity Of Small Businesses Is An Important Tool For Creating Productive Jobs. InternationalEngineeringJournalForResearch\&Development, 5(6), 99.

Ismoilov, R. B., \&Matkarimov, K. Zh.,KhaidarovKh. Kh., Nabotova Z. The role of the teacher in the educational process: addressed training of specialists of secondary professional education in the process of network interaction. materials of the IV All-Russian scientific-practical conference with international participation. Institute for the Development of Territorial Systems of Professional Education, 167-174.

ErgashevJamshidJaliddinovich,. (2020). Peculiarities Of Small Business And Private Entrepreneurship Development In Uzbekistan. International Engineering Journal For Research \& Development, 5(6), 10. https://doi.org/10.17605/OSF.IO/QK79M

Shermatov, A., \&Isakova, N. I. (2020). Development Of The Organization Of Agro-Cluster Activities In Agriculture. The American Journal of Management and Economics Innovations, 2(09), 17-29.

Bakhriddinovich, I. R., Bulturbayevich, M. B., Gulomjanovna, M. N., \&Karimjanovich, U. R. (2020). Use Of Modern Marketing Research In The Context Of Market Development. InternationalEngineeringJournalForResearch\&Development , 5(SpecialIssue), 8-8. 
Abdurashidovich, B. D., Bakhriddinovich, I. R., \&Bulturbayevich, M. B. (2020). The State Of Development Of Small Business And Private Entrepreneurship During The Coronavirus Pandemic. InternationalEngineeringJournalForResearch\&Development, 5( Speciallssue), 8-8.

Abduganievich, A. U., Bakhriddinovich, I. R., \&Bulturbayevich, M. B. (2020). Current Situation Of Investment In The National Economy. International Engineering Journal For Research \& Development, 5(Special Issue), 7-7.

Bulturbayevich, M. B., Saodat, S., \&Shakhnoza, N. (2020). Innovative Activity Of Small Businesses Is An Important Tool For Creating Productive Jobs. InternationalEngineeringJournalForResearch\&Development, 5(6), 99.

Bulturbayevich, M. B., \&Jurayevich, M. B. (2020). The Impact Of The Digital Economy On Economic Growth. InternationalJournalofBusiness, Law, andEducation, 1(1), 4-7.

Mullabaev, B. B. (2018). Econometric Analysis Of Vertical Integration Of The Light Industry Enterprises Of The Namangan Region (On The Example Of The Republic Of Uzbekistan). ScientificReview: TheoryandPractice,(8), 22, 36.

Mullabayev, B. B. (2018). Economic analysis of vertical integration integration of the Namangan region (on the prerogative of the Republic of Uzbekistan). Scienceoftheory: theoryand practice"-8.

Bachtijarzhan, M. (2017). Development Of Light Industry Branches In Uzbekistan Based On Vertical Integration. Бюллетень науки и практики, (10 (23)).

AbdulxakimovZuhraliTursunalievich, \&SaydalievaUmidhonSolijonqizi. (2020). Establishment And Use Of Small Eco-Zones In The Development Of Recreational Activities. International Engineering Journal For Research \& Development, 5(Special Issue), https://doi.org/10.17605/OSF.IO/XN79M

AbdukakhorovUlugbekAbduganievich, IsmoilovRavshanjonBakhriddinovich, AbdulxakimovZuhraliTursunalievich, \&BakhriddinovJahongirRavshanjonogli. (2020). Development Of Physical Training And Sports In The Republic Of Uzbekistan. International Engineering Journal For Research \& Development, 5(Special Issue), 8. https://doi.org/10.17605/OSF.IO/W6E72

IsakovaNaimaIkromjonovna, \&AbdulxakimovZuhraliTursunalievich. Agricultural Clusters In Agriculture. International Engineering Journal For $\begin{array}{llll}\text { Research } \& \text { Development, } & \text { 5(Special } & \text { Issue), } & 8 .\end{array}$ https://doi.org/10.17605/OSF.IO/Q94EK

AbdulxakimovZuhraliTursunalievich,\&IbadullaevErgashBakturdievich. (2020). Treatment And Rehabilitation Of Tourism And Recreation. International Engineering Journal For Research \& Development, 5(Special Issue), 8. https://doi.org/10.17605/OSF.IO/JCNUW 
